\title{
Školní zahrady středních škol a jejich potenciál pro environ- mentální výchovu
}

Štěpánka Chmelová, Renata Ryplová, Zbyněk Vácha, Olga Vaněčková, Miroslav Procházka

\section{Envigogika 14 (1) - Recenzované články/ Reviewed articles}

Publikováno / Published 22. 5. 2019

DOI: $\underline{10.14712 / 18023061.580}$

\begin{abstract}
Abstrakt
Využití školních zahrad ve výuce přírodovědných disciplín zaživá v posledních letech svou renesanci. Ačkoli $v$ České republice jsou tradičně školní zahrady využivány $v$ environmentální výchově na základních školách, $v$ zahraničí je za prínosnou považována i výuka $\checkmark$ prostředí středoškolských školních zahrad. $V$ českém prostředí však neexistují aktuální informace o tom, jak jsou využívány školní zahrady středních škol a zda jejich vybavení a provoz skýtá potenciál využitelný $v$ environmentální výchově. $\vee$ př́spěvku jsou prezentovány výsledky sondy zjištujíći stav a vybavení školních zahrad středních škol v rámci tří regionů České republiky. Získané výsledky jsou diskutovány s ohledem na potenciál využití středoškolských zahrad v environmentální výchově. Dotazníkové šetření probíhalo na 16 středních školách disponujících školní zahradou.
\end{abstract}

\section{Klíčová slova}

školní zahrady, střední školy, environmentální výchova

\begin{abstract}
Recently, the revival of the use of school gardens in science education is documented. Although for environmental education usually the school gardens of basic schools are used in the Czech Republic, foreign studies document also a positive impact of school gardens on environmental education at high school level. Unfortunately, actual information from the Czech Republic about the equipment, ways of use or potential for the use in environmental education of high school gardens are missing. This article brings results of a survey that questiones situation, equipment and use of high school gardens in three regions of the Czech Republic. The results are discussed from the point of view of the potential use of high school gardens in environmental education. The survey was done at 16 high schools that use gardens in education.
\end{abstract}

\section{Key words}

school gardens, high schools, environmental education 


\section{Úvod}

\section{Úloha školních zahrad v environmentální výchově mládeže}

Výuka v prostředí školních zahrad má celosvětově dlouhou tradici. Je potěšitelné, že i mezinárodní studie zmiňují jako průkopníka environmentální výchovy s využitím školních zahrad v našeho "učitele národů" J. A. Komenského (Subramaniam, 2002; Desmond a kol., 2004). Úlohou školních zahrad v Evropě a Austrálii byla v počátcích, tj. v 19. století, především tzv. polytechnická výchova, zaměřená na pěstitelství, zemědělskou výrobu a vytváření pracovních návyků. Naopak v Americe byla původní úloha školních zahrad spíše estetická (Desmond a kol., 2004), teprve později s rozvojem farmářství i zde převládla výchova k pěstitelství. Velký význam byl celosvětově přisuzován školním zahradám během druhé světové války a těsně po ní v souvislosti s nutností zajištění potravinových zdrojů, zatímco s nástupem technického rozvoje $v$ Americe $v$ padesátých letech došlo naopak k útlumu jejich využívání (Subramaniam, 2002). V posledních desetiletích zdůrazňuje zahraniční literatura u školních zahrad zejména funkci environmentální (Desmond, 2002; Malone a Tranter, 2003; Blair, 2009). Např. Bundschu-Mooney (2003) vidí ve výuce v prostředí školních zahrad možnost přímého kontaktu žáků s přírodou během každodenní výuky a zdůrazňuje nezbytnost tohoto kontaktu pro zdravý intelektuální i duševní rozvoj mládeže v dnešním technicky orientovaném světě. Výuka v prostředí školních zahrad mưže být prínosná i pro profesní rozvoj samotných učitelů. Např. studie Ray a kol. (2013) zmiňuje pozitivní vliv vyučování na školní zahradě na postoje učitelů vưči tzv. "trvale udržitelné výuce" (sustainable education).

Využívání areálů školních zahrad ve výuce se v posledních desetiletích opět stává celosvětovým trendem. To Ize vypozorovat zejména v Americe v posledních 30 letech (Blair, 2009; Bundschu-Mooney, 2003), zřejmě souvisí s nárůstem potřeby "návratu k přírodě" v převážně konzumně orientované americké společnosti. $V$ posledních letech můžeme renesanci školních zahrad pozorovat i v Evropě (Dyg a Wistoft, 2018; Kangas a kol., 2014; Köhler \& Benkowitz, 2014). Rozvoj výuky v prostředí školních zahrad přispěl v didaktické oblasti ke vzniku termínu "garden based education" (Desmond, Greishop, \& Subramaniam, 2004; Williams \& Brown, 2012) v českém překladu označovaném jako "zahradní pedagogika".

\section{Školní zahrady v českém vzdělávání}

Školní zahrady v České republice mají velmi bohatou historii (Morkes, 2007) a jsou chápány jako univerzální výukové prostory a prostředky (Burešová, 2007; Chmelová, 2010). $\checkmark$ druhé dekádě 21 . století je v prostoru školních zahrad zřejmá zvýšená snaha o vytváření tzv. přírodních učeben. Přírodní učebna mưže sloužit jako ukázka nejrůznějších biotopů, druhů a odrůd ovocných dřevin, zemědělských a technických plodin, ale i léčivých a okrasných rostlin, nebo může nabídnout zážitek ze smyslové stezky (Čtvrtečková, 2012). Výuka na školních zahradách tak nabízí velké možnosti pro vnímání environmentálních souvislostí. Využitím školních zahrad pro environmentální výchovu se zabývá řada center pro environmentální vzdělávání (např. Lipka, Chaloupky, o.p.s). Křivánková (2012) přímo navrhuje možnosti využití školní zahrady jako přírodní učebny.

Školní zahrady se tradičně zřizují především u základních škol. Informace o stavu školních zahrad při základních školách v minulosti přinesla Burešová (2007), která na základě rozsáhlého výzkumu zmapovala jejich aktuální stav, vybavení a využití. Do výzkumu se zapojilo 486 škol z celé ČR, z toho 80,5 \% škol s vlastní zahradou. Obdobným tématem se zabýval Vácha (2015), který zjištóval využití školních zahrad na primárním stupni základních škol. V rámci této analýzy bylo sledováno 119 základních škol, z toho 86 škol s vlastní 
zahradou. Bylo zjištěno, že zahrady jsou používány nejenom pro výuku jednotlivých vzdělávacích oblastí, ale i např. $k$ projektovým dnům $v$ rámci průřezových environmentálních témat. Aktivním zapojením žáků do vyučování prímo $v$ prírodních učebnách může být do budoucna podpořen pozitivní vztah žáků $\mathrm{k}$ prírodovědným předmětům a k přírodě vůbec. Jak je to ale se zahradami středních škol? Nabízí jejich aktuální stav, vybavení a praktické využívání ve výuce potenciál pro středoškolskou environmentální výchovu? Jsou středoškolské zahrady ve výuce využívány, a pokud ano, s jakými problémy se jejich provozovatelé setkávají? Studie dokumentující současný stav školních zahrad při středních školách dosud chybí.

\section{Střední školy a environmentální výchova}

V České republice je k loňskému školnímu roku vedeno celkem 1307 středních škol (MŠMT, 2017). Střední škola má charakter konečné etapy vzdělávání (absolventi přecházejí rovnou na trh práce) nebo tranzitivní fázi vzdělávání (připravuje absolventy na terciární nebo jiné navazující vzdělávání) (Průcha, 2009). Střední školy v Česku poskytují bud' všeobecné, nebo odborné střední vzdělání. Všeobecné střední vzdělání zajištují na úrovni úplného středního vzdělání gymnázia. Odborné střední vzdělání zajištúují bud' střední odborná učiliště (střední odborné vzdělání) nebo střední odborné školy (úplné střední odborné vzdělání).

Environmentální výchova představuje na všech typech středních škol jedno z důležitých prưřezových témat. Teoretický základ pro uvedené prưřezové téma je ukotven $v$ celé řadě vzdělávacích oborů, a to jak prírodovědných (hlavně $v$ tématech ekologie a člověk $a$ životní prostředí), tak v oborech společenskovědních. Dochází k propojování poznatků a zkušeností z různých oborů a tyto zkušenosti a poznatky jsou potom využívány pro konkrétní řešení environmentálních problémů $v$ praxi. Také $z$ tohoto důvodu není obsah průřezového tématu zpracován tradičně - pouhým výčtem učiva. Mezi klíčová témata patř́ biodiverzita, vztahy mezi organismy a prostředím, téma člověk a životní prostředí, životní prostředí regionu a České republiky. Důležitým aspektem je nejen vlastní obsah výuky, ale i používané pomůcky a prostředí.

Významnou součástí realizace prưřezového tématu Environmentální výchova proto může být např. i ekologizace provozu a prostředí školy (tedy i příslušných školních zahrad), rešení problémů v obci a jejím okolí a spolupráce $s$ různými partnery mimo školu. Průřezové téma Ize u středních škol ve školním vzdělávacím programu realizovat různými metodami a formami v rámci teoretického a praktického vyučování, ale i prostřednictvím mimoškolních aktivit, případně zařazením samostatného vyučovacího předmětu. $V$ odborné složce je toto průřezové téma diferencovaně začleněno do obsahových okruhů podle charakteru jednotlivých oborů vzdělání (NúV, 2009).

V návaznosti na cíle environmentálního vzdělávání se nabízí možnost využití školních zahrad pro tuto oblast vzdělávání. Byl prokázán pozitivní vliv výuky v prostředí školních zahrad na posílení a zvýšení environmetálních postojů u žáků základních škol (Aguilar a kol., 2018). Z výsledků šetření Situmorang a Tarigan (2018) vyplynulo, že učením prostřednictvím aktivit se zahradou studenti střední školy dosáhli dobrého pochopení ekologických krizí, rovnováhy prírody, antropocentrizmu a dalších environmentálních problémů.

Některé odborné střední školy mají k dispozici právě školní zahrady, ev. botanické zahrady či arboreta. Školní botanické zahrady a arboreta se využívají hlavně pro výuku oborových předmětů, pro odbornou praxi a k výchově žáků a studentů ke vztahu k př́rodě a $\mathrm{k}$ její ochraně. Vedle toho mohou být některá tato zařízení otevírána i pro veřejnost a pro jiné školy, než pro ty, ke kterým dané zařízení patř́i (Smáhová, 2014). Informace o stavu školních zahrad při gymnáziích a jejich využívání ve výuce se bohužel v dostupné literatuře nepodařilo dohledat. 
Vzhledem k nedostatku informací o aktuálním stavu a využívání středoškolských školních zahrad, které by umožňovaly diskutovat jejich potenciál pro využití v environmentální výchově, vyvstala potřeba provést deskriptivní výzkum, jehož výsledky přináší následující příspěvek. Cílem výzkumu bylo především ověřit vybavenost školních zahrad jednotlivých středních škol. Základní výzkumnou otázkou pak bylo zjistit, jakým způsobem využívají a jaké další možnosti využití poskytují středním školám školní zahrady, a to ve vztahu $\mathrm{k}$ jejich vybavení, personálnímu zajištění výuky a k možnosti poskytnout zázemí pro environmentální výchovu.

\section{Metodika výzkumu}

\section{Dotazníkové šetření}

Cílem výzkumu bylo zjistit aktuální informace o stavu, vybavení a využívání středoškolských zahrad ve výuce $v$ krajích česko rakouského příhraničí s ohledem na jejich potenciál pro využití v environmentální výchově. Cílem výzkumu nebylo zjistit, jaké procento středních škol zahradu využívá, ale analyzovat informace o tom, jaké jsou podmínky na školních zahradách aktivně využívaných ve výuce na středních školách. Tím byl také omezen výběr participujících /podmínkou spolupráce byla dispozice školní zahrady). Výzkum volně navazuje na šetření stavu využívání školních zahrad na základních školách v minulých letech (Burešová, 2007; Vácha, 2015). Výzkum probíhal v rámci projektu EDUGARD Interreg ATCZ65, který se zabýval tématem zahradní pedagogiky $v$ príhraničních regionech Rakouska a Česka. Vzhledem $\mathrm{k}$ tomu byl výzkum proveden pouze $v$ regionech $v$ tomto projektu zúčastněných, $\mathrm{tj}$. $v$ Jihočeském, Jihomoravském a $v$ regionu Vysočina. Do výzkumu bylo zapojeno 16 středních škol.

Potřebná data k výzkumu byla získávána pomocí dotazníkového šetření prováděného mezi středoškolskými pedagogy aktivně vyučujícími na školních zahradách a mezi řediteli zúčastněných škol. Dotazníkové šetření bylo uskutečněno od března do záŕí roku 2017 a bylo zajištěno osobním jednáním na všech zmiňovaných středních školách. Dotazník pro ředitele školy tvořilo celkem 8 otevřených či polouzavřených otázek, které obsahovaly úvodní identifikační údaje, obecné popisné informace o školní zahradě, dále otázky týkající se prínosů či problémů při provozování školní zahrady, eventuálních plánů na změnu koncepce zahrady a otázku cílenou na zjištění zájmu o další vzdělávání pedagogických pracovníků v oblasti zahradní pedagogiky.

Druhý typ dotazníku byl určen pro pedagoga, který aktivně na školní zahradě vyučoval a měl dle sdělení ředitele školy zahradu tzv. "na starost”. Dotazník se skládal z části demografické, zjištujujíci věk, vzdělání a délku pedagogické praxe respondenta a z části zaměřené na popis vybavení a využívání školní zahrady (znění popisné části dotazníku uvádí přiloha č. 1).

Paralelně probíhalo na školách účastnících se této studie také dotazníkové šetření mezi studenty, zaměřené na názory studentů na výuku s využitím školních zahrad a její význam pro studentskou agrární gramotnost. Výsledky této sondy provedené mezi celkově 334 studenty zmíněných škol jsou obsaženy v publikaci Ryplová a kol. (2018).

\section{Charakteristika výzkumného vzorku}

Do výzkumu bylo zapojeno celkem 16 středních škol se školní zahradou. Participovat tak mohli pouze zaměstnanci školy, které aktivně využívají školní zahradu ve výuce. Jednalo se tedy o formu tzv. dostupného výběru (Chráska, 2016). Přestože v rámci středního školství 
jsou školními zahradami vybaveny především školy odborně zaměřené (zahradnické, zemědělské, atd.), do výzkumného vzorku se podařilo zahrnout i gymnázia disponující školní zahradou. Celkově sedm zúčastněných škol bylo z regionu Vysočina, čtyři z Jihočeského a pět z Jihomoravského kraje. Odborné zaměření jednotlivých škol zobrazuje obrázek č. 1.

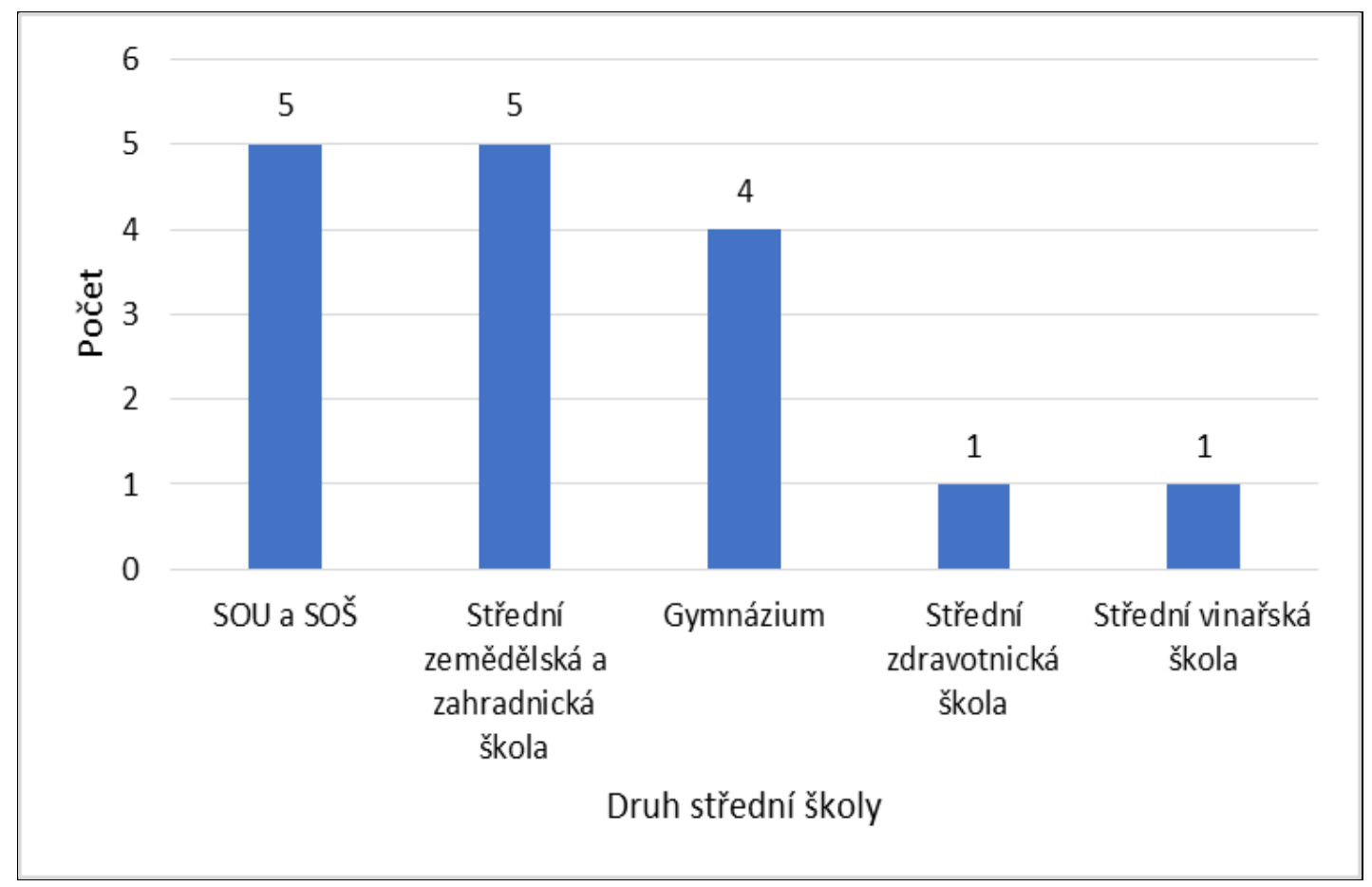

Obrázek č. 1: Odborné zaměření jednotlivých škol (údaje uvedeny v kumulativních četnostech, $\mathrm{n}_{\mathrm{i}}=16$ )

Získaná data byla statisticky zpracována pomocí 3D grafů tak, aby bylo možno rozlišit údaje charakterizující výuku na školních zahradách gymnázií od údajů charakterizující výuku na středních odborných školách, u nichž, vzhledem $\mathrm{k}$ jejich zaměření, Ize předpokládat odlišný způsob využívání i vybavení školních zahrad.

Školy se nacházely převážně v menších obcích $s$ počtem méně jak 10 tis. obyvatel (9 škol) 1 škola $v$ obci do 20 tis. obyvatel, 2 školy $v$ obci do 50 tis. obyvatel, 2 v obci do 100 tis. obyvatel a 2 školy $\vee$ obci nad 100 tis. obyvatel. Učitelský dotazník vyplňovali učitelé s průměrnou délkou praxe 12 let (minimum praxe 2 roky, maximum 29 let), genderově pak 5 mužů a 11 žen. Průměrný věk vyučujících činil 44 let. Většina pedagogů měla odborné vysokoškolské vzdělání nepedagogického směru, převažovali absolventi MZLU (Mendelova zemědělská a lesnická univerzita $\vee$ Brně) $\vee$ Brně (56 \%). Vzdělání vyučujících bylo později doplněno pedagogickým nebo specializovaným studiem pro koordinátory EVVO (Environmentální vzdělávání, výchova a osvěta) (50 \% dotazovaných).

\section{Výsledky}

Výsledky shrnují celkové závěry z obou dotazníkových šetření mezi učiteli a řediteli středních škol. 
Nejstarší zahrada byla založena již v roce 1870, nejmladší vybudovaná zahrada byla založena až v roce 2017. Polovina zahrad byla založena již před rokem 2000, ostatní až $v$ pozdějších letech. Většina školních zahrad $(94 \%)$ je přímo $v$ areálu střední školy, jen jedna se nachází mimo areál školy, ale do 10 minut chůze od budovy školy. $Z$ hlediska certifikace zahrad jako Př́rodní zahrady a Ukázkové prírodní zahrady je pouhých 37 \% zkoumaných zahrad certifikováno, zbytek zahrad (63\%) je bez certifikace (obr. 2).

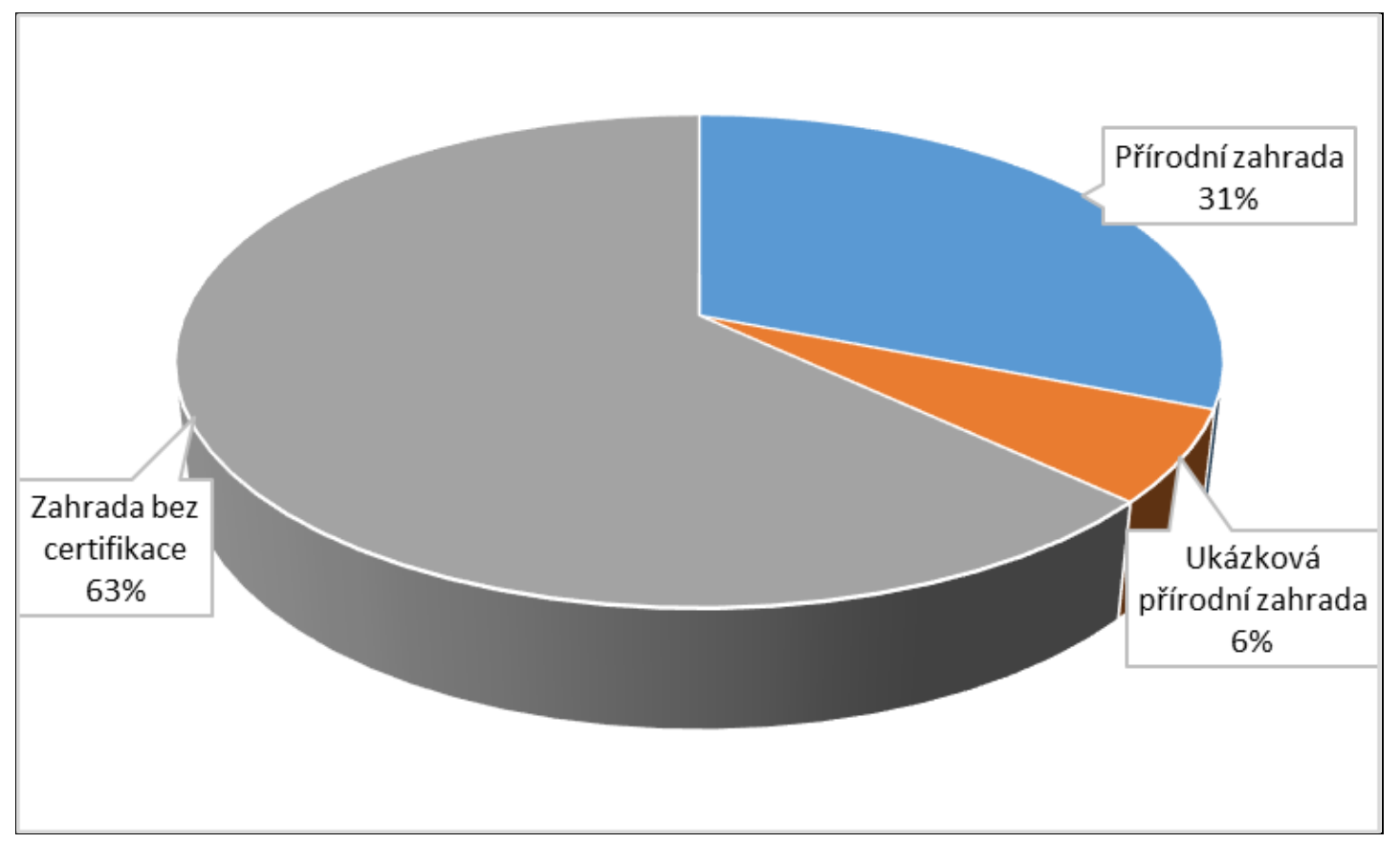

Obrázek č. 2: Certifikace prírodních zahrad (údaje uvedeny $v$ relativních četnostech, $\mathrm{n}_{\mathrm{i}}=$ $16, \mathrm{f}_{\mathrm{i}}=100 \%$ )

Necelé dvě třetiny zahrad mají rozlohu větší než $1000 \mathrm{~m}^{2}$ (obr. č. 3). Pět z uvedených zahrad má rozlohu $v$ rozmezí 101-500 $\mathrm{m}^{2}$. Pouze jedna zahrada vykazuje rozlohu 501 až $1000 m^{2}$. Menší rozlohy zahrad se týkají především školních zahrad u gymnázií. 
12

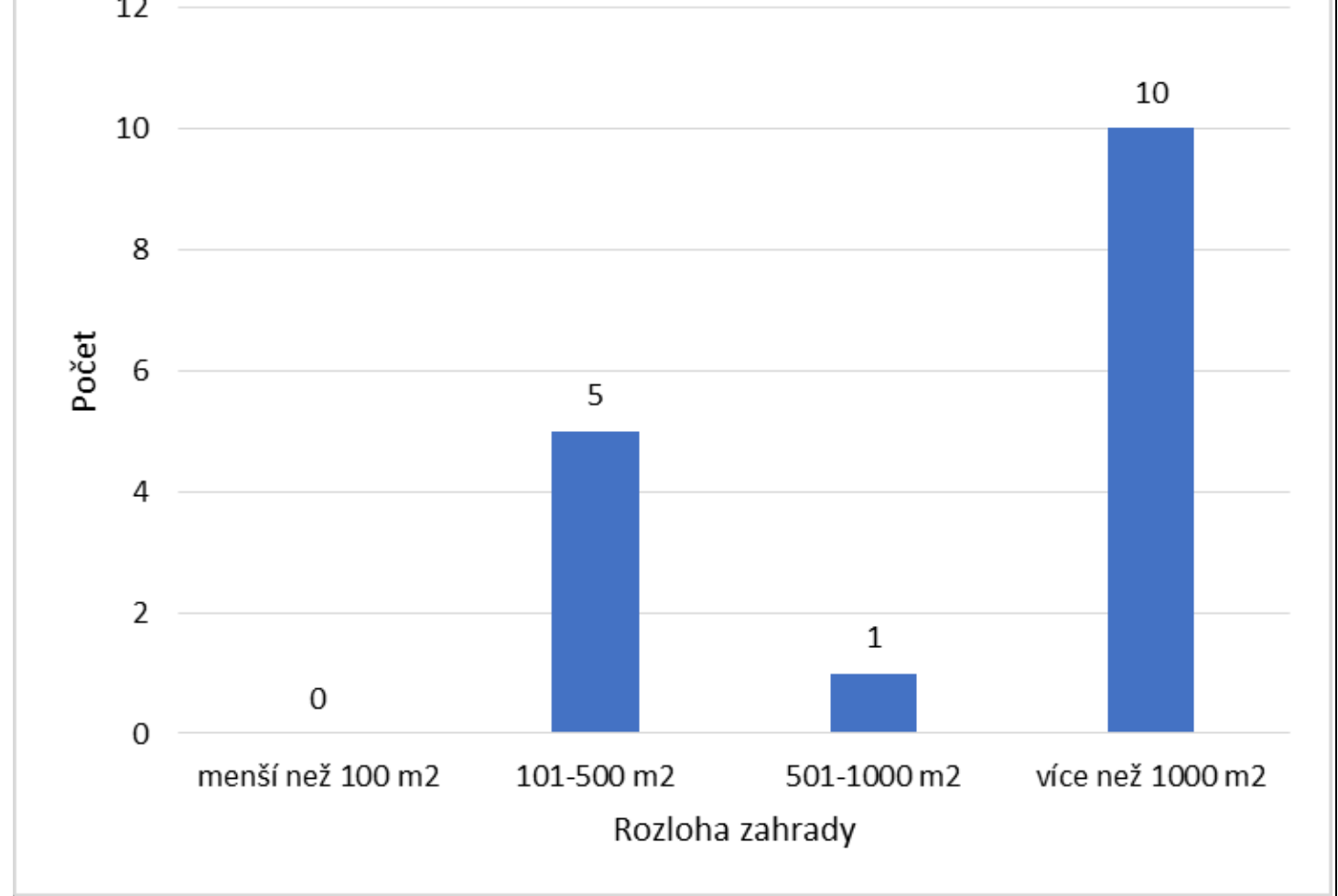

Obrázek č. 3: Velikost středoškolských školních zahrad (údaje uvedeny v kumulativních četnostech, $\mathrm{n}_{\mathrm{i}}=16$ )

Vybavení zahrad středních škol je velmi různorodé a odpovídá standardnímu vybavení pro požadavky na současné školní zahrady při základních školách (Chmelová, 2010), chybí samozřejmě prvky typické pro mladší věkové kategorie, jako vrbové stavby a pískoviště, které nalezneme u zahrad základních a mateřských škol. Rovněž žádná z testovaných zahrad nemá chovatelské zařízení, které vyžaduje náročná organizační a legislativní opatření. Z hlediska environmentální výuky je jistě důležité, že nadpoloviční většina zahrad má vybudovaná různá biotopová stanoviště (suché stanoviště 10 , vodní biotop 8 , květnatá louka 6 , broukoviště 5). Za zmínku stojí i vybavení meteorologickou stanicí u většiny škol. Pouhé dvě školy nemají na zahradě kompost. Přehled četností jednotlivých typů vybavení je uveden $v$ tabulce 1 . 
Tabulka 1: Přehled uvedeného vybavení školních zahrad středních škol (údaje uvedeny $v$ kumulativních četnostech s možností vícečetné odpovědi, $\mathrm{n}_{\mathrm{i}}=16$ )

\begin{tabular}{|c|c|c|c|}
\hline Vybavení zahrady & $\begin{array}{l}\text { Četnost výskytu } \\
\left(n_{\mathrm{i}}=16\right)\end{array}$ & Gymnázia & SS/SOU \\
\hline Pěstební oddělení (záhony) & 14 & 3 & 11 \\
\hline Kompost & 14 & 4 & 10 \\
\hline Nevytápěný skleník & 10 & 1 & 9 \\
\hline $\begin{array}{l}\text { Biotop suché stanoviště - zídka, } \\
\text { skalka }\end{array}$ & 10 & 3 & 7 \\
\hline Venkovní učebna (altán, pergola) & 10 & 3 & 7 \\
\hline Meteorologická stanice & 10 & 1 & 9 \\
\hline Ovocný sad & 9 & 0 & 9 \\
\hline Informační tabule & 9 & 1 & 8 \\
\hline Vodní biotop - jezírko & 8 & 3 & 5 \\
\hline Hmyzí hotel & 7 & 2 & 5 \\
\hline Bylinková spirála & 7 & 2 & 5 \\
\hline Vytápěný skleník & 6 & 0 & 6 \\
\hline Květnatá louka & 6 & 2 & 4 \\
\hline Broukoviště & 5 & 2 & 3 \\
\hline Herní prvky pro děti & 3 & 0 & 3 \\
\hline Geologická stezka & 2 & 1 & 1 \\
\hline Zelená střecha & 2 & 1 & 1 \\
\hline Hmatová stezka & 1 & 0 & 1 \\
\hline Jiné & 1 & 1 & 1 \\
\hline Pískoviště & 0 & 0 & 0 \\
\hline Vrbové stavby & 0 & 0 & 0 \\
\hline Chovatelský koutek & 0 & 0 & 0 \\
\hline
\end{tabular}

$\mathrm{n}_{\mathrm{i}}=$ celkový počet, $\mathrm{SS} / \mathrm{SOU}=$ střední odborné školy a střední odborná učiliště

Jako ostatní (jiné) vybavení respondenti uváděli garáže, zahradní techniku a živé ploty. 
Z hlediska pěstovaných rostlin převládá zastoupení běžné zeleniny, ovocných stromů a keřů, léčivých a okrasných rostlin. Pěstování polních plodin je pak doménou hlavně středních odborných škol. Malý podíl pak tvoří celkově vodní a vlhkomilné rostliny (obr. 4)

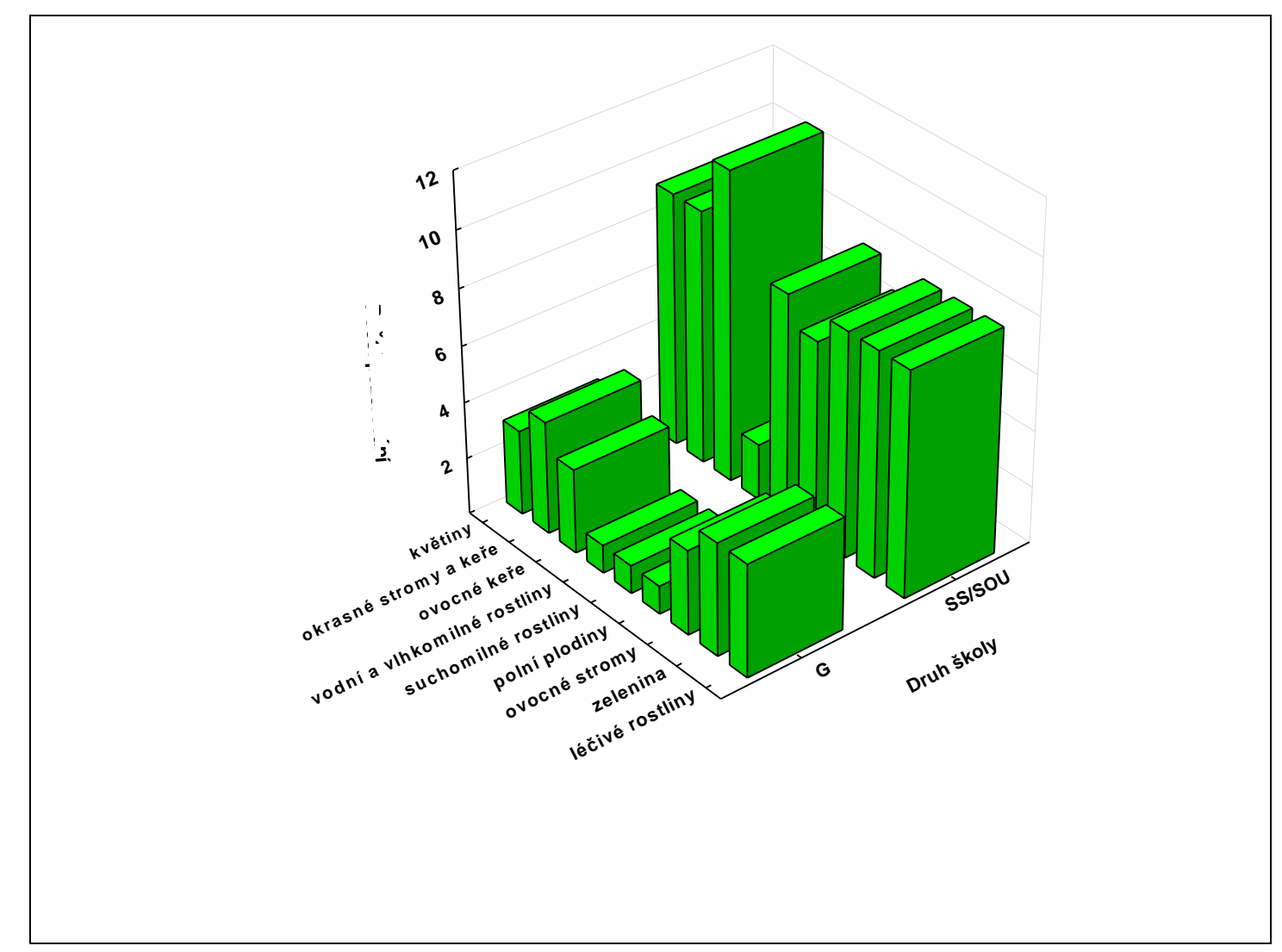

Obrázek č. 4: Pěstované druhy rostlin na školních zahradách ( $G$ = gymnázia, $\mathrm{SS} / \mathrm{SOU}=$ střední odborné školy a střední odborná učiliště, $\mathrm{n}_{\mathrm{i}}=16$ )

Využití výpěstků ze školních zahrad ukazuje obrázek č. 5. Nejvíce se využívají pro výuku a školní pokusy, na druhém místě je pak rozdělení pěstovaných rostlin mezi učitele a žáky. Na třetím místě je pak spotřeba výpěstků ve školní jídelně. 


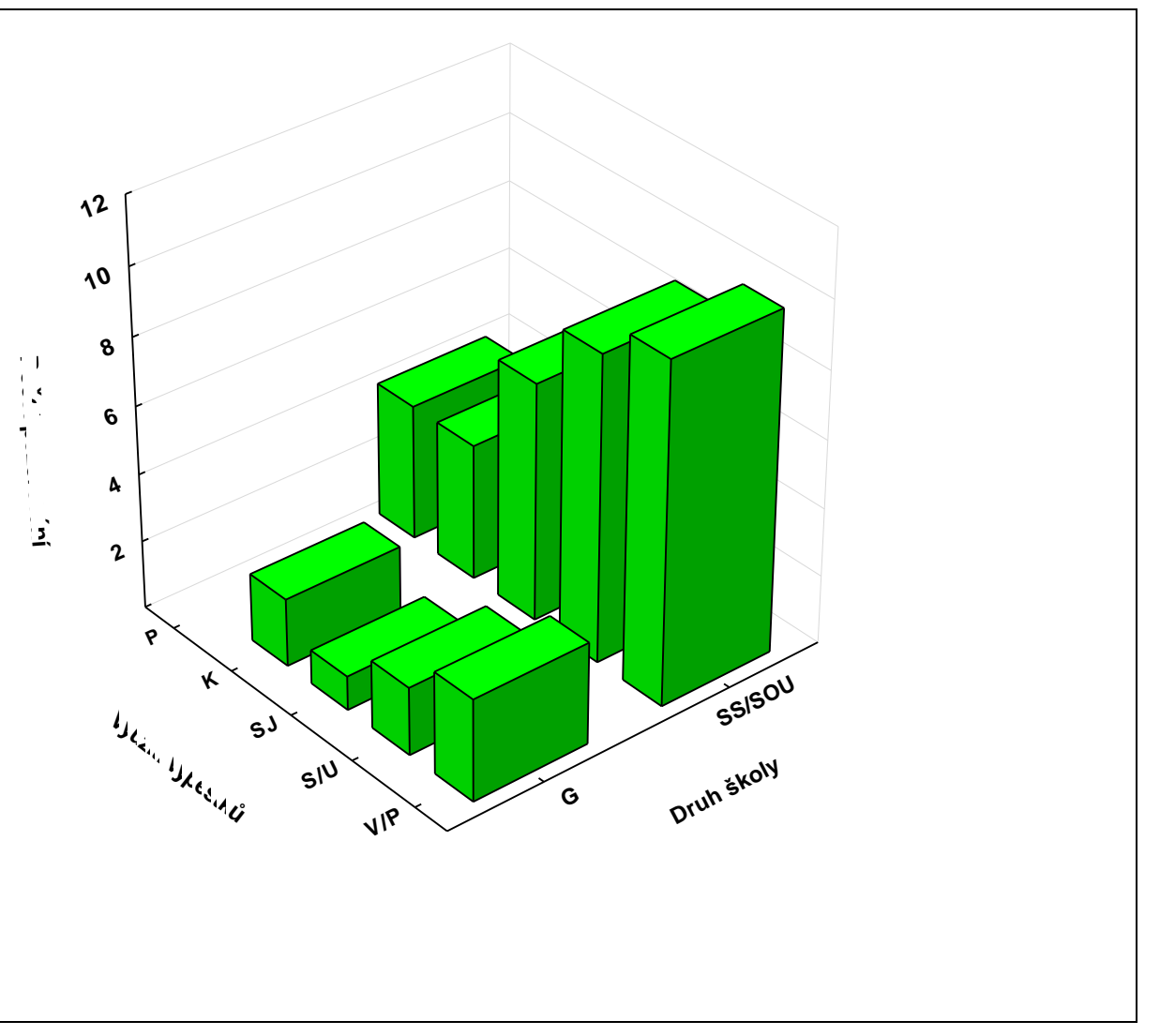

Obrázek č. 5: Využití výpěstků ze školních zahrad (G = gymnázia, SS/SOU = střední odborné školy a střední odborná učiliště, $\mathrm{V} / \mathrm{P}=$ využití výpěstků pro výuku a pokusy, $\mathrm{S} / \mathrm{U}=$ rozdělení výpěstků studentům a učitelům, $\mathrm{SJ}=$ spotřeba výpěstků ve školní jídelně, $\mathrm{K}=\mathrm{vy}-$ užití pro kompostování, $\mathrm{P}=$ prodej, $\mathrm{n}_{\mathrm{i}}=16$ )

Provoz školní zahrady zabezpečuje především pedagog s aprobací pěstitelské práce či se zemědělským nebo zahradnickým vzděláním (75\%), ve zbylých $25 \%$ pak pedagog bez příslušné aprobace. Celkem tři odborné školy ještě mají k dispozici pomocný technický personál - zahradníka. Celkem $44 \%$ dotazovaných škol nevyužívá $k$ péči žádné jiné subjekty, $13 \%$ využivá dobrovolníky a $33 \%$ technický a další personál školy. Problém v období letních prázdnin řeší polovina škol (50 \%) především formou žákovských služeb a praxí, druhá polovina péči zajišttuje formou služeb pedagogů a technického personálu školy. Do výuky na školní zahradě je zapojeno $v$ jednotlivých školách $v$ průměru 5 učitelů (jako maximum uvedeno 15 učitelů, minimum 1 učitel).

Z dotazovaných škol jich sedm (44\%) nemá stabilní hodinovou dotaci pro výuku na školní zahradě. Ostatní odpovědi se diametrálně liší, počty hodin závisí na zaměření a odbornosti střední školy. $V$ počtu hodin praktické výuky na školní zahradě vedou samozřejmě školy zemědělské a zahradnické, kde počty praktických hodin byly uváděny v rozmezí 100120 hod. během školního roku, nejvíce pak střední řemesIná škola (až 400 hod. za rok pro 3. ročník). Minimum počtu hodin věnují výuce na školní zahradě gymnázia a střední zdravotnická škola (0-2 hod. ročně dle jednotlivých ročníků).

Velmi zajímavé je zastoupení předmětů vyučovaných na školní zahradě (obr. 6). 


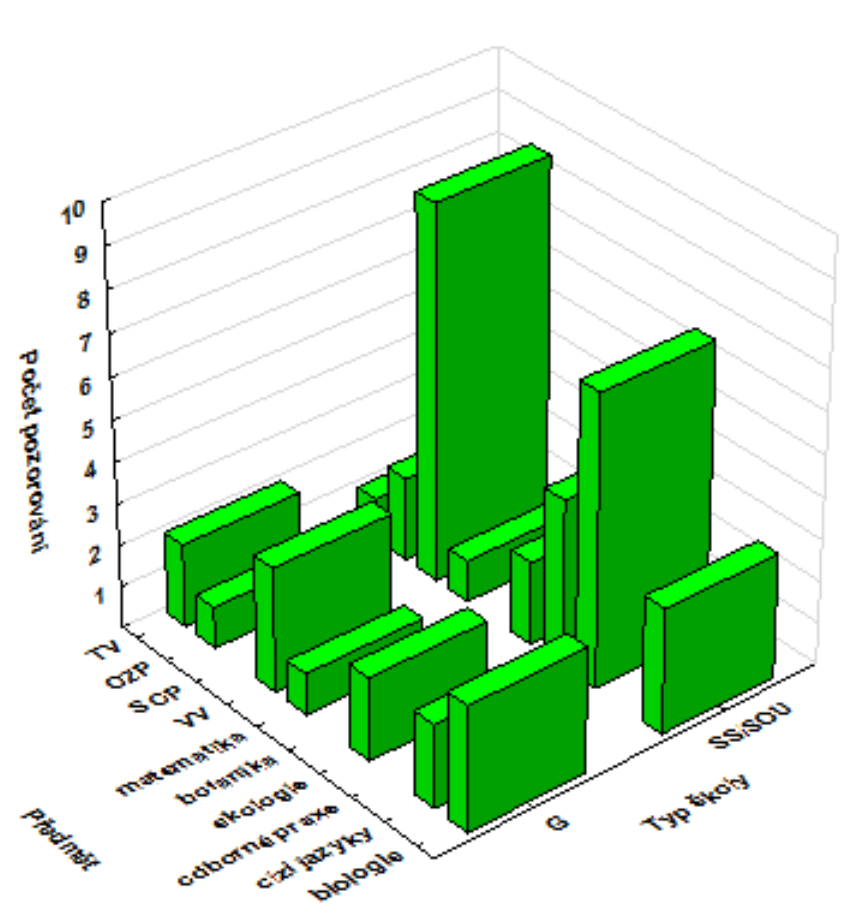

Obrázek č. 6: Zastoupení vyučovacích předmětů na školní zahradě. ( $G=$ gymnázia, $\mathrm{SS} / \mathrm{SOU}=$ střední odborné školy a střední odborná učiliště, $\mathrm{TV}=$ tělesná výchova, OZP = ochrana životního prostředí, SOP = specifické odborné předměty pro daný typ střední odborné školy nebo učiliště, $\mathrm{VV}=$ výtvarná výchova, $\mathrm{n}_{\mathrm{i}}=16$ )

Nejvíce se výuka na školních zahradách zaměřuje na praktické a odborné předměty. Zde vynikají zejména zemědělské a zahradnické střední školy. Na druhém místě jsou pak z hlediska počtu odborné praxe studentů a třetí místo souhrnně zaujímá výuka biologie. $\mathrm{Na}$ čtvrtém místě následuje souhrnně výuka ekologie. U gymnázií převládá na školních zahradách hlavně výuka biologie a výtvarné výchovy. Ochrana životního prostředí je zmiňována sporadicky. Spektrum předmětů v rámci škol je ale velmi široké. Environmentální výuka patří k mezioborovým tématům, proto je pro její uplatnění v rámci využívání školních zahrad velký potenciál.

Všechny uvedené školy využívají školní zahradu kromě výuky i pro jiné účely - jako park a místo pro odpočinek studentů, pro sportovní a pohybové aktivity, pro práci zájmových útvarů organizovanými školou nebo jinými subjekty, pro možnost prodeje a produkce rostlinného materiálu a pro akce pro veřejnost - zejména trhy, výstavy a víkendy otevřených zahrad (ty zmiňovaly hlavně školy s certifikovanou Přírodní zahradou a Ukázkovou přírodní zahradou). Jedna ze škol uvedla i využití zahrady formou zahradní terapie pro klienty speciálních center.

Na zahradu či její rozvoj, dobudování nebo přebudování získalo 69 \% škol finanční prostředky z různých fondů (př́slušné krajské úřady), grantů (Operační programy, projekty EU) či sponzorských darů. Právě finanční problémy uvádí většina dotazovaných ředitelů škol 
jako hlavní limity při provozování zahrad. Obrázek č. 7 znázorňuje hlavní problémy s provozem školních zahrad.

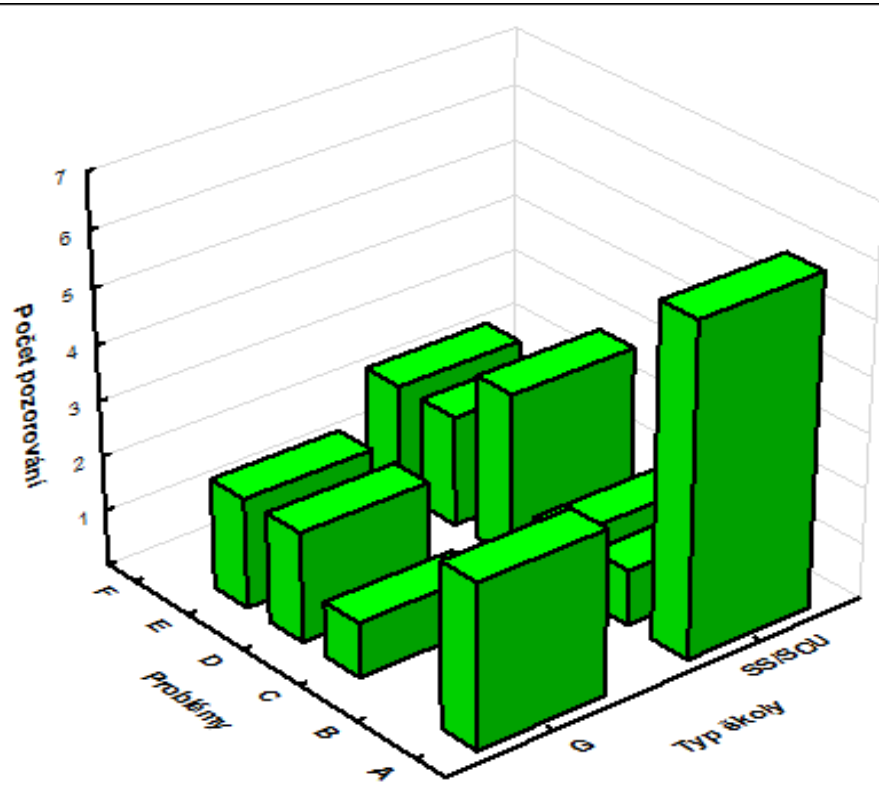

Obrázek č. 7: Problémy s využiváním a provozem školních zahrad gymnázií (G) a středních odborných škol a učilišt́ ( SS/SOU). A - finanční problémy, B - problémy s počty studentů ve skupinách, $C$ - časové možnosti, D - personální problémy, E - údržba o hlavních prázdninách, $\mathrm{F}-$ žádné problémy, $\mathrm{n}_{\mathrm{i}}=16$

Odpovědi ředitelů škol na tuto otevřenou otázku bylo potřeba roztř́́dit do několika kategorií, které jsou pak v obr. č. 7 souhrnně znázorněny. Po finančních problémech jsou často uváděny ještě problémy personální, jak u středních odborných škol, tak u gymnázií.

Naopak př́nosy výuky na školních zahradách jsou dle ředitelů škol významné. Obrázek č. 8 ukazuje hlavní přínosy školních zahrad. 


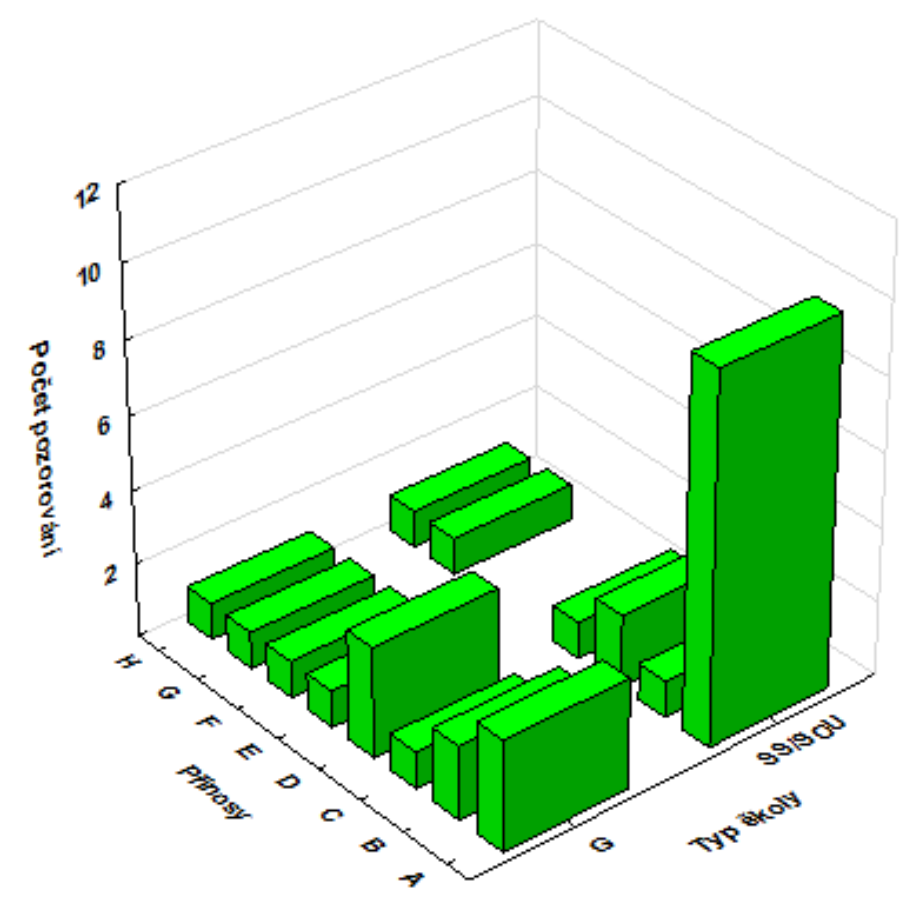

Obrázek č. 8: Hlavní přínosy školních zahrad gymnázií (G) a středních odborných škol a učilišt' (SS/SOU). A - praktická výuka a praxe, B - kladný vztah k př́rodě, C - zdroj zdravých potravin, využití v kuchyni, D - zlepšení areálu školy, E - relaxace, trávení volného času, F - rozvoj manuálních dovedností, návyků, G - pobyt na čerstvém vzduchu, H - zpestření výuky, $\mathrm{n}_{\mathrm{i}}=16$

Kromě výše zmiňovaných př́nosů ještě zahrady podporují mezipředmětové vztahy a propojují teorii s praxí (Chmelová, 2010). Školy uváděly ojediněle ještě možnost pestřejší realizace školních vzdělávacích programů (ŠVP), někde i finanční zisky z prodeje rostlin.

Z dotazovaných škol již devět škol (56 \%) neplánuje koncepční změny na školních zahradách, zbytek škol většinou uvádí plán vybudovat altány či obnovit venkovní sezení, ev. doplnit do zahrady vodní biotop.

Polovina dotazovaných ředitelů škol nemá zájem o další vzdělávání pedagogických pracovníků v oblasti realizace a inovace výuky na školních zahradách, zbytek se přiklání ke vzdělávání nových pedagogů a zmiňuje zájem stávajících učitelů se dále vzdělávat.

\section{Diskuze a závěr}

Do výzkumu byly zapojeny střední školy, které vlastní a využívají školní zahradu. Nebyl tedy sledován faktor početního zastoupení školních zahrad na středních školách. Sledováno bylo pět středních zemědělských a zahradnických škol, dále pět SOU a SOŠ, čtyři gymnázia, jedna zdravotnická škola a jedna střední škola vinařská. Oblasti výskytu škol mají přesah do tří krajských oblastí České republiky. Většina sledovaných školních zahrad má rozlohu větší jak 1000 m². To se diametrálně liší od výzkumu Váchy (2015), který zjistil 
obvyklé velikosti školních zahrad základních škol v rozmezí $100-500 \mathrm{~m}^{2}$. Zahrady středních škol jsou tedy zpravidla větší než školy základních škol, a proto se zde nabízí možnost zvýšení jejich biodiverzity a podpory k rozvoji environmentální výchovy. Svědčí o tom např. velké zastoupení různých biotopových stanovišt', např. květnaté louky, vodní biotopy apod. (viz tabulka 1).

Stále přetrvává hlavně pěstitelská funkce školních zahrad. Stejné výsledky uvádí Burešová (2007) a Vácha (2015). Při porovnání s tímto výzkumem vyplývá, že zde chybí herní prvky pro děti, což je logické, protože to je doména školních zahrad základních a mateřských škol. Chybí zde i chovatelské koutky. Chovatelství má velký vliv na pochopení environmentální problematiky a přispívá k posílení environmentální senzitivity žáků (Jančaříková, 2008; Kellnerová, 2013). Školní zahrady umožňují chovy drobného zvířectva, ale zde je jejich funkce stále ještě nedoceněná. Dle Morkese (2007) ke školním zahradám v minulosti vždy patřily i chovy drobného zviŕectva. Burešová (2007) rovněž zjistila malý podíl chovatelských zařízení na školních zahradách. Samozřejmě chov zviŕat ve školách je velmi náročný na provoz a je nutné dodržovat řadu legislativních opatření související s chovem zviŕat ve školách (Kellnerová, 2013).

Z pěstovaných rostlin převládá zastoupení běžné zeleniny, ovocných stromů a keřu, léčivých a okrasných rostlin. Jak ukázala také naše paralelně probíhající studie (Ryplová a kol., 2018) zelenina a ovocné stromy a keře jsou také rostliny, které studenti sami mají zájem pěstovat na školních zahradách. Tato studie také prokázala, že studenti považují výuku v prostředí školních zahrad důležitou pro získání znalosti polních plodin a způsobů jejich pěstování. Oproti minulým letům jsou však také posíleny ukázky biotopových stanovišt́ a pěstování léčivých rostlin. Existenci biotopových stanovišt́ na školních zahradách uváděly jak gymnázia, tak i střední odborné školy. Žáci se tak učí nejen pěstovat užitkové rostliny, ale př́mo mohou sledovat i biodiverzitu a posilují tak znalosti z ochrany prírody. Všechny tyto aspekty tvoří velký potenciál pro prưřezové téma environmentální výchovy.

Výpěstky ze školních zahrad se využívají nevíce pro výuku a školní pokusy nebo se rozdají žákům a učitelům, částečně se využijí i ve školních jídelnách, jak zjistil obdobně u základních škol i Vácha (2015). Podporuje se tak zdravé stravování a může se zvyšovat konzumace ovoce a zeleniny (Loso, 2018). Ratcliffe (2009) prímo ověřil pozitivní význam výuky na školních zahradách středních škol v souvislosti s konzumací zeleniny. O př́nosu školních zahrad pro zdravé stravování hovoří také Dyg a Wistoft, 2018.

Celkem $44 \%$ dotazovaných středních škol nemá stabilní hodinovou dotaci pro výuku na školní zahradě. Nejvíce jsou zahrady využívány pro výuku praktických a odborně zaměřených předmětů a pro realizaci praxe žáků. Zde vynikají hlavně zemědělské a zahradnické školy. Obdobně je to i u gymnázií, která nemají stanovenou hodinovou dotaci pro výuku na školních zahradách. Nejvíce se prostredí školních zahrad na gymnáziích využívá zejména pro výuku biologie a výtvarné výchovy. Rozdíly výsledků jsou ovšem způsobeny velkou variabilitou zkoumaných škol. Na základních školách jsou využivány zahrady hlavně pro pěstitelské práce (Burešová, 2007) a vzdělávací oblast Člověk a svět práce (Vácha, 2015).

Všechny uvedené školy využívají školní zahradu i pro jiné účely (např. jako park a místo pro odpočinek studentů, pro sportovní a pohybové aktivity, jinými školami stejného nebo jiného typu, pro práci zájmových útvarů organizovanými školou nebo jinými subjekty, pro možnost prodeje a produkce rostlinného materiálu) a vévodí i akce pro veřejnost a víkendy otevřených zahrad. Zahrady tedy plní také funkce komunitní. Zajímavé je i uvedení využití zahrady formou zahradní terapie pro klienty speciálních center. 
Největším zjištěným problémem při provozování školních zahrad byly finanční zdroje. Až 69 \% škol získalo finanční prostředky na dobudování zahrad ještě z jiných zdrojů. $\mathrm{Na}$ druhém místě jsou uváděny problémy personální, zejména zajištění odborných vyučujících a rovněž technického personálu. Burešová (2007) uvádí rovněž jako největší problémy právě finanční, dále nedocenění učitele, který má zahradu na starost a nízkou hodinovou dotaci v učebních plánech základních škol.

Převážná většina škol pečuje o školní zahrady svépomocí, nevyužívá k péči o zahrady jiné subjekty. $Z$ tohoto důvodu vyvstávají problémy se zajištěním péče o zahradu $v$ období letních prázdnin. Tento problém řeší polovina škol (50\%) především formou žákovských služeb a praxí, druhá polovina péči zajištuje formou služeb pedagogů a technického personálu školy. Zde se výsledky Burešové (2007) liší - autorka zjistila, že z 61,9 \% pečuje o školní zahradu základních škol během prázdnin technický personál-školník, žáci pouhými 18,4 \%. U středních odborných škol je tedy péče během hlavních prázdnin vyrovnanější, protože se i $v$ této době realizují středoškolské praxe a zahrady tak mohou být řádně udržovány.

Jako největší prínos školních zahrad středních škol je uváděna možnost praktické výuky a odborné praxe žáků, dále pak zdroj zdravých potravin a podpora kladného vztahu k prírodě. Již Harvey (1990) uvádí, že výuka v prostředí školní zahrady pozitivně ovlivňuje proenvironmentální postoje žáků. Blair (2009) a Ozer (2007) zmiňují, že školní „jedlé" zahrady jsou důležité pro výchovu ke zdravé výživě. $V$ této výchovné a vzdělávací části mají školní zahrady důležitou úlohu a poměrně značné rezervy (Ratcliffe, 2009).

Budování, ev. pořizování školních zahrad je chápáno jako nutná modernizace škol, směřující k trvale udržitelnému rozvoji (Lukáš, 2010). Prostředí školních zahrad se navíc jeví jako vhodné pro uplatňování moderních aktivizačních metod a př́stupů, jako je např. badatelská výuka (Vácha a Petr, 2013). Ye a kol. (2008) ve své studii zaměřené na výuku $k$ trvale udržitelnému rozvoji poukazují na to, že ačkoliv badatelská výuka je ve světě široce rozšířená a Ize ji považovat za globální trend, málo se uplatňuje ve výuce ekologických témat. Na možné spojení badatelské výuky s environmentální výchovou poukazuje v českém prostředí práce Ryplové a Rehákové (2011). Spojení badatelské výuky s terénní výukou se navíc zdá být u žáků velmi oblíbené (Ryplová, 2017). Školní zahrady, tedy prostředí umožňující spojení výuky badatelské s výukou terénní, se proto jeví jako vhodné pro moderní pojetí environmentální výchovy. $Z$ výsledků této studie vyplývá, že školy, které zahradní pedagogiku aktivně praktikuji (at' už jsou to školy odborné či gymnázia), využívají školní zahradu $\checkmark$ poměrně širokém spektru předmětů. Využití školní zahrady tedy také splňuje předpoklady pojetí středoškolské environmentální výchovy jako prưřezového tématu využívajícího poznatky z prírodovědných a odborných předmětů. Blair (2009) posoudila a potvrdila význam školních zahrad pro environmentální výchovu. Rovněž Prokop a kol. (2007) potvrdil ve svém výzkumu význam terénní výuky na posílení environmentálních vědomostí žáků. Zvýšené znalosti žáků zaznamenal i Kvasničák $(2011,2013)$, který v rámci výuky v prostředí školních zahrad zjistil lepší znalosti žáků o půdních ekosystémech.

Navíc vzhledem $k$ tomu, že všechny zúčastněné školy využívají školní zahradu i k jiným aktivitám mimo výuku, umožňují školní zahrady středních škol posílení kontaktu mládeže s prírodou (Williams \& Brown, 2012) a posilují vztah a empatii ke zvíratům, hmyzu a rostlinám (Dyg \& Wistoft, 2018).

\section{Poděkování}

Výzkum byl umožněn v rámci projektu Egugard ATCZ65. 


\section{Literatura}

- Aquilar, O. M., Waliczek, T. M., Zajicek J. M. (2018). Growing environmental stewards: the overall effect of school gardening program on environmental attitudes and environmental locus of control of different demographic groups of elementary school children. Hortechnology. April-June 18(2), 243-249.

- Blair, D. (2009). The child in the garden: An evaluative review of the benefits of school gardening. Journal of Environmental Education, 40 (2), 7-78.

- Bundschu-Mooney, E. (2003). School garden investigation: Environmental awareness and education. San Rafael, CA: Division of Education, School of Business, Education and Leadership, Dominican University of California. Retrieved from https://files.eric.ed.gov/fulltext/ED480981.pdf

- Burešová, K. a kol. (2007). Učíme se v zahradě. Kněžice: Středisko environmentální a ekologické výchovy Chaloupky, 497 s.

- CČtvrtečková, T. (2012). Ideální zahrada mateřské školy podle představ dětí předškolního věku (na 6. MŠ v PIzni a MŠ Resslova Praha). Bakalářská práce, Západočeská univerzita $v$ Plzni, 45 s.

- Desmond, D., Grieshop, J., Subramaniam, A. (2004). Revisiting garden-based learning in basic education. International Institute for Educational Planning. Retrieved from http://www.fao.org/3/a-aj462e.pdf

- $\quad$ Dyg, P. M., Wistoft, K. (2018). Wellbeing in school gardens - the case of the Gardens for Bellies food and environmental education program. Environmental Education Research, 24(8), 1177-1191.

- Harvey, M. R. (1990): The Relationship between Children's Experiences with Vegetation on School Grounds and Their Environmental Attitudes. The Journal of Environmental Education, 21(2):9-15

- Chmelová, Š. (2010). Pěstitelství na základní škole I. Didaktika výuky. České Budějovice: Jihočeská univerzita v Českých Budějovicích, 114 s.

- Chráska, M. (2016). Metody pedagogického výzkumu. Grada Publishing Praha, 254 s. ISBN 978-80-247-5326-3

- Jančaříková, K. (2008). Zkušenosti s chovem exotických zvířat v českém školství. Sborník příspěvků konference Terapie a asistenční aktivity lidí za pomoci zvířat. Praha: Česká zemědělská univerzita, 1. vyd., 53-58.

- $\quad$ Kangas M., Vesterinen O., Lipponen L., Kopisto K., Salo L. \& Krokfors L. (2014). Students' agency in an out-of-classroom setting: Acting accountably in a gardening project. Learning, Culture and Social Interaction, 3, 34-42.

- Kellnerová, D. (2013). Chov zvířat ve školách. Metodický materiál pro učitele. Lipka Brno, $83 \mathrm{~s}$.

- Křivánková, D. (2012). Školní zahrada jako přírodní učebna. Lipka Brno. 76 s. ISBN: 978-80-87604-62-5 
- Köhler, K., \& Benkowitz, D. (2014). Supporting awareness of urban biodiversity: school garden, Schoolyard and school surrounding. In: Kabisch, N., Larondelle, N., Artmann, M. \& A. Reeve (ed.): Human-Environmental Interactions in Cities - Challenges and Opportunitites of Urban Land Use, Planning and Green Infrastructure. Cambridge Scholars Publishing, Cambridge, S. 100-114.

- Kvasničák, R. (2011). Vplyv skúsenotného vyučovania v prírodných podmienkach na predstavy žiakov o ekosystéme. Pedagogika roč. LXI, s. 175-186. Retrieved from http://pages.pedf.cuni.cz/pedagogika/?p=824\&lang=cS

- Kvasničák, R. (2013). Krátkodobý vplyv skúsenostného vyučovania v teréne na vedomosti žiakov o ekosystéme. Pedagogika 2/2013. s. 198-219. Retrieved from http://pages.pedf.cuni.cz/pedagogika/? $p=557$ \&lang $=c S$

- Loso, J., Staub, D., Colby S. E., Olfert, M. D., Kattelmann, K., Vilaro, M., Colee, J., Zhou, W., Franzen-Castle, L., Mathews A. E. (2018). Gardening experience is associated with increased fruit and vegetable intake among first-year college students: A cross-sectional examination. Journal of the Academy of Nutrition and Dietetics, vol. $118(2), 275-282$.

- Lukáš, M. (2010). Školní zahrada jako učebna. Bakalářská práce. MU FF Brno, 37 s.

- Malone, K., Tranter P.J. (2003) School grounds as sites for learning: making the most of environmental opportunities Environ. Educ. Res., 9 (3) pp. 283-303

- Morkes, F. (2007). Učíme se v zahradě. Kněžice: Středisko environmentální a ekologické výchovy Chaloupky

- MŠMT (2017) databáze. Retrieved from http://www.msmt.cz/vzdelavani/skolstviv-cr/statistika-skolstvi/vyvojova-rocenka-skolstvi-2006-07-2016-17

- Národní ústav pro vzdělávání (2009). Retrieved from http://www.nuv.cz/t/rvp-os

- Ozer, E. (2007). The effects of school gardens on student and schools: conceptualization and considerations for maximizing healthy development. Health Education and Behavior, 34, 846-863.

- Prokop, P., Tuncer, G., Kvasničák, R. (2007). Short-term effects of field programme on students' knowledge and attitude toward biology: a Slovak experience. Journal of Science Education and Technology, Vol. 16, No.3, p. 247-255.

- Průcha, J. (2009). Pedagogická encyklopedie. Praha: Portál, 59 s.

- Ratcliffe, M. M., Merrigan, K. A., Rogers, B. L., Goldberg, J. P. (2011). The effects of school garden experiences on middle school-aged students' knowledge, attitudes, and behaviors associated with vegetable consumption. Health Promot Pract. 12(1): 36-43. doi: $10.1177 / 1524839909349182$

- Ray, J., Wei, K. M., Barrett, D. (2013). Effect of experience-based school learning gardens professional development program workshop on teachers' attitudes towards sustainability education. Journal of Sustainability Education 5: 2151-7452 
- Ryplova, R. (2017). Inquiry education in botany - a way to cope with plant blindness? In M. Rusek, Vojiŕ K.(Eds.), Project-based Education in Science Education: Empirical texts XV, Praha: Charles University in Prague, Faculty of Education, 120-128.

- Ryplová, R., Chmelová, Š., Vácha, Z., Vaněčková, O., Procházka, M. (2018). A survey of High School Students' Attitudes to Agriculture and Garden Education. In Čtrnáctová, Nesměrák, Teplá, DidSci Plus - Research in Didactics of Science, Proceedings of the International Conference, Charles University - Faculty of Science, Prague, 25th-27th June 2018. Praha : Univerzita Karlova, Přírodovědecká fakulta, 2018 , s. 337-343.

- Ryplová, R., Reháková, J. (2011). Př́nos badatelsky orientovaného vyučování (BOV) pro environmentální výchovu: Př́padová studie implementace BOV do výuky na ZŠ. Envigogika 2011/VI/3 Retrieved from http://www.envigogika.cuni.cz/index.php/cz/recenzovane-clanky/2011/envigogika-2011vi3/606-prinos-badatelskyorientovaneho-vyucovani-bov-pro-environmentalni-vychovu-pripadova-studie-implementace-bov-do-vyukyna-zs

- Situmorang, R. P., Tarigan, S. D. (2018). Cultivating students'environmental awareness by creating bottle garden in school, a qualitative study. Indonesian Journal of Biology Education, 4(3), 263-270.

- Smáhová, M. (2014). Vybrané botanické zahrady a arboreta středních škol v České republice a jejich využití ve výuce. Bakalářská práce, KU PF Praha, 83 s.

- Subramaniam, A. (2002). Garden-based learning in basic education: A historical review. Monograph, 1-11. Retrieved from http://www. whatkidscando.org/featurestories/2009/11_school_gardens/pdf/School\%20Garden\%20History.pdf

- Vácha, Z. \& Petr J. (2013) Inquiry based education at primary school trought school garden. Journal of International Scientific Publications: Education Alternatives, 4, 219-230.

- Vácha Z. (2015). Didaktické využití školních zahrad v České republice na primárním stupni základních škol. Scientia in educatione 6(1), 80-90.

- Williams, D. R. \& Brown, J. D. (2012). Learnign gardens and sustainability education. Taylor\& Francis, Nex York, 227s. ISBN 13:978-0-415-89981-9

- Ye, Z. N., Barker, S., Rowell, P., Reyes, P., Zhou, J. Z., Jenkins, F., Wang, M., Fuentes, E. L. (2008). Globalization of science inquiry and education for sustainable development. MBE 2008: Asia - Pacific conference on mind brain and education, 108-112. 


\section{Příloha č. 1: Dotazník pro učitele SŠ - popisná část}

\section{Údaje o zahradě}

1. Kde se vaše školní zahrada nachází?

a) je součástí areálu školy

b) zahrada je dostupná do 10 minut chůze od školy

c) zahrada je dostupná nad 10 minut chůze od školy

2. Je vaše zahrada certifikována jako přírodní zahrada?
a) ano, jako Přírodní zahrada
b) ano, jako Ukázková prírodní zahrada
c) ne

3. Součástí školní zahrady je:
a) nevytápěný skleník
b) vytápěný skleník
c) pěstební oddělení (záhony)
d) ovocný sad
e) bylinková spirála
f) broukoviště
g) vodní biotop - jezírko
h) biotop suché stanoviště - zídka (ještěrkovník) či skalka
i) geologická stezka
j) venkovní učebna (jakéhokoli typu, např. altán, pergola)
k) chovatelský koutek
I) meteorologická stanice
m) kompost
n) vrbové stavby
o) herní prvky pro děti
p) pískoviště
q) hmyzí hotel
r) hmatová stezka
s) květnatá louka
t) informační tabule
u) zelená střecha
v) jiné:

4) Jaké typy rostlin se pěstují na vaší školní zahradě:
a) zelenina
b) ovocné stromy
c) ovocné keře
d) okrasné stromy a keře
e) léčivé rostliny
f) polní plodiny
g) květiny - letničky, trvalky...
h) suchomilné rostliny
i) vodní a vlhkomilné rostliny
j) jiné: 
5) Jak využíváte výpěstky ze školní zahrady?
a) využití ve školní jídelně
b) využití pro výuku a školní pokusy
c) prodej (i sazenice)
d) rozdělí se dětem a učitelům
e) kompostují se
f) zahradu nevyužíváme k pěstování, výpěstky nemáme

6) Provoz školní zahrady zabezpečuje:
a) pedagog s aprobací pěstitelské práce či se zemědělským nebo zahradnickým vzdě- láním
b) pedagog bez aprobace pěstitelské práce či bez zemědělského nebo zahradnického vzdělání (včetně učitele přírodopisu/biologie, bez aprobace pěstitelské práce)
c) jiná osoba

7) Využíváte v péči o zahradu i jiné subjekty a dobrovolníky?
a) ano, dobrovolníky
b) ano, jiné subjekty (Jaké?)
c) ne

8) Jak řešíte péči o školní zahradu v období letních prázdnin?
a) pravidelné služby skupin žáků
b) jiným způsobem - Jak? Kdo?

9) Má vaše škola stabilní hodinovou dotaci pro výuku na školní zahradě? (Popřípadě kolik hodin přibližně stráví žáci na školní zahradě v průběhu jednoho školního roku?)
a) 1. ročník
b) 2. ročník
c) 3. ročník
d) 4. ročník

10) Uvedte prosím vyučovací předměty, v jejichž rámci je zahrada žáky využívána

11) Další využití školní zahrady:

A) Mimo výše uvedenou výuku je školní zahrada využívána také
a) jako park (místo pro odpočinek studentů, např. o přestávkách)
b) pro sportovní a pohybové aktivity
c) jinými školami stejného typu
d) jinými školami jiného typu
e) pro práci zájmových útvarů organizovaných školou
f) pro práci zájmových útvarů organizovaných jinými subjekty, spolky
g) produkce rostlinného materiálu
h) pro veřejnost (uvedte jak konkrétně)
i) jinak: (uvedte jak).

B) Není využívána jinak než ve výuce 